\title{
THE CENTENARY OF THE CANADIAN FISHERIES EXPEDITION (1914/15): AN IMPORTANT MILESTONE IN THE HISTORY OF NORTH AMERICAN MARINE RESEARCH
}

\author{
MICHAEL SINCLAIR* \\ Bedford Institute of Oceanography \\ P.O. Box 1006, Dartmouth, NS B2Y 4A2
}

Jennifer Hubbard, a history professor at Ryerson University, provides an excellent synthesis of the Canadian Fisheries Expedition, including the influence of the Norwegian expedition leader (Johan Hjort) on the development within Canada and the United States of America of an ecological and oceanographic approach to fisheries issues (Hubbard, 2014). Vera Schwach (at the Nordic Institute for Studies in Innovation, Research and Education in Oslo, Norway), in the same volume, also provides a synthesis of Hjort's brilliance as a scientist and leader (Schwach 2014). The report on the expedition, which was published by the Department of the Naval Service, Ottawa, is still a great read (Hjort 1919). Due to the fortunate timing of this two year study a century ago, the approach to addressing the fisheries issues of the day could be considered revolutionary.

The expedition followed closely Hjort's synthesis (published in 1914) of the Migration Committee work carried out under the guidance of the International Council for the Exploration of the Sea (ICES). The mandate of the committee, which was established at the initiation of ICES in 1902, was to solve the reasons for the decadal scale fluctuations in the landings of the Great Fisheries of Northern Europe, in particular those for cod and herring. In the $18^{\text {th }}$ and $19^{\text {th }}$ century during the good years for fishing (with abundant landings), the economies of Northern Europe were robust, whereas during the poor years society at large suffered. The issue being addressed by ICES was high profile within several northern European countries adjacent to the North Sea and the North Atlantic waters, and thus the stakes for the continuation of ICES beyond the first few years of initial funding were high.

\footnotetext{
* Author to whom correspondence should be addressed: Michael Sinclair

E-mail: michael.sinclair@dfo-mpo.gc.ca
} 
The extant hypothesis, based on the Polar Migration concept developed in 1746 by Johann Anderson, the mayor of Hamburg at that time, interpreted that the local fluctuations were caused by variable migration patterns of relatively constant abundance levels of the diverse, commercially important groundfish and small pelagic species (Wegner 1993). In essence the fluctuations in any particular area were considered to be due to an edge effect caused by climate variability; the overall abundance levels of the species were considered to be invariable, whereas local abundance varied due to migration patterns of the species. The scale required to address the issue under "migration thinking" was large (i.e. the northeast Atlantic as a whole). The title of this inaugural ICES Committee (the Migration Committee) reflected the current hypothesis of the day, an elaboration of the ideas of the Hamburg mayor from the mid- $18^{\text {th }}$ century.

The radical new interpretation by Hjort (1914) could be termed a paradigm shift, in the true sense of Kuhn (1962). Under this new thinking being developed within ICES, fish species were considered to be comprised of populations or in the language of the early $20^{\text {th }}$ century, "races". Some species like herring and salmon are characterized by many populations, whereas other species such as mackerel and tuna have only a few. At the extreme end of the scale of richness one species, the European eel, was hypothesized to be panmictic, i.e., there is a single population for the species. Thus population richness (and their diverse spawning areas) was considered to be a species specific trait, which needed to be described and interpreted. Furthermore the abundance levels of the populations/"races" of the diverse species were concluded to be variable on decadal time scales due to year-class variability. The observed variability in year-classes was considered to be caused by oceanographic processes. In addition, the spatial scale of the problem of the fluctuations of landings under population thinking, in contrast to species thinking, shrunk to some degree for some commercial species. A detailed analysis of the shifts in perspective on research strategies with respect to fisheries issues at the time of the Canadian Fisheries Expedition was provided by Sinclair and Smith (2002) on the occasion of the centenary of the founding of ICES.

In essence the Migration Committee, during about a decade of international multi-disciplinary ecological and oceanographic studies, redefined the very nature of the societal issue of "fluctuations in the 
great fisheries" of northern Europe. Thus the timing of the Canadian Fisheries Expedition was very fortunate. The questions asked by Hjort and his colleagues were ecological and oceanographic, rather than being focused on the search for biogeographical laws in the tradition of Darwin and Wallace, and as carried out in the oceans in the Challenger (1872-1876) and Michael Sars (1910) expeditions, respectively. The Canadian Fisheries Expedition initiated modern oceanographic and marine ecological research in North America. We owe a great intellectual debt to ICES, and in particular to the Scandinavian scientific leaders who participated in the expedition a century ago.

In October, 2014, ICES organized a symposium in Bergen, Norway (the Johan Hjort Symposium on Recruitment Dynamics and Stock Variability) to celebrate the centenary of the publication of the classic paper by Hjort (1914). Canada was very well represented at the gathering, illustrating that the seeds of marine science planted by Johan Hjort and his team a century ago have born considerable fruit. Furthermore, in 2016, the Canadian Journal for Fisheries and Aquatic Sciences published a volume on the proceedings of the symposium (Can. J. Fish. Aquat. Sci., Volume 73). These past few years have been a time for Canadian marine scientists to celebrate the magnificent contribution by the mostly Scandinavian team of scientists, who a century ago initiated our field of research in support of management of ocean uses.

\section{REFERENCES}

Hjort, J. (1914). Fluctuations in the great fisheries of northern Europe. Rapport et Proces-Verbaux des Reunions du Conseil International pour l'Exploration de la Mer, 20:228 pp.

Hjort, J. (1919). Canadian Fisheries Expedition 1914-1915: Investigations in the Gulf of St. Lawrence and Atlantic Waters of Canada. Department of the Naval Service, Ottawa. Available at archive.org/stream/ canadianfisheries00cana\#page/n3/2up.

Hubbard, J. (2014). Johan Hjort: The Canadian Fisheries Expedition, International Scientific Networks, and the challenge of modernization. ICES J. Mar. Sci.71:2000-2007. Kuhn, T.S. (1962). The Structure of Scientific Revolutions, University of Chicago Press, Chicago, Illinois, USA. 172 pp.

Schwach, V. (2014). A Sea Change: Johan Hjort and the natural fluctuations in the fish stocks. ICES J. Mar. Sci. 71:1993-1999. 
Sinclair, M.M. and Smith, T.D. (2002). The notion that fish species form stocks. ICES Marine Science Symposia, 215:297-304.

Wegner, G. (1993). Ein Hamburger Burgermeister und seine Heringstheorie (1746) (A mayor of Hamburg and his theory concerning herring. 1746). Deutsche Hydrographische Zeitscrrift, Erganzungsheft B(German Journal of Hydrography, Supplement B), N0. 25, 14 pp. (In German). 